\title{
Recombinant human VEGF $_{165}$ b protein is an effective anti-cancer agent in mice
}

\author{
Emma S. Rennela,f, ${ }^{a}$, Maryam A. Hamdollah-Zadeha,g, Edward R. Wheatley ${ }^{b, f}$, Anette \\ Magnussen $^{a}$, Yvonne Schüler ${ }^{a}$, Sara P. Kelly ${ }^{c}$, Ciara Finucane ${ }^{d}$, David Ellison ${ }^{d}$, Stephanie

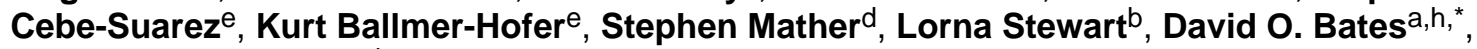 \\ and Steven J. Harpera,i
}

aMicrovascular Research Laboratories, Department of Physiology and Pharmacology, School of Veterinary Science, University of Bristol, Southwell Street, Bristol BS2 8EJ, United Kingdom ${ }^{b}$ Cancer Research Technologies, Cruciform Building, Gower Street, London, United Kingdom 'Department of Physiology and Pharmacology, Medical School, University Walk, Bristol BS8 1TD, United Kingdom dNuclear Medicine Research Lab, Barts and the London School of Medicine, Queen Mary, London, United Kingdom ePaul Scherrer Institute, Laboratory of Biomolecular Research, Molecular Cell Biology, 5232 Villigen-PSI, Switzerland

\section{Abstract}

Tumour growth is dependent on angiogenesis, the key mediator of which is vascular endothelial growth factor-A (VEGF-A). VEGF-A exists as two families of alternatively spliced isoforms pro-angiogenic $\mathrm{VEGF}_{\mathrm{xxx}}$ generated by proximal, and anti-angiogenic $\mathrm{VEGF}_{\mathrm{xxx}}$ b by distal splicing of exon 8 . $V_{E G F} 165$ inhibits angiogenesis and is downregulated in tumours. Here, we show for the first time that administration of recombinant human $V_{E G F}{ }_{165} \mathrm{~b}$ inhibits colon carcinoma tumour growth and tumour vessel density in nude mice, with a terminal plasma half-life of $6.2 \mathrm{~h}$ and directly inhibited angiogenic parameters (endothelial sprouting, orientation and structure formation) in vitro. Intravenous injection of ${ }^{125} \mathrm{I}_{-} \mathrm{VEGF}_{165} \mathrm{~b}$ demonstrated significant tumour uptake lasting at least $24 \mathrm{~h}$. No adverse effects on liver function or haemodynamics were observed. These results indicate that injected $\mathrm{VEGF}_{165} \mathrm{~b}$ was taken up into the tumour as an effective anti-angiogenic cancer therapy, and provide proof of principle for the development of this anti-angiogenic growth factor splice isoform as a novel cancer therapy.

\section{Keywords}

VEGF; VEGF 165 b; Anti-angiogenesis; Cancer inhibition; Pharmacokinetics; Liver toxicity

\footnotetext{
(C) 2008 Elsevier Ltd. All rights reserved.

*Corresponding authors: Tel.: +44 117928 9818; fax: +44 117928 8151. E-mail addresses: Emma.Rennel@bris.ac.uk (E.S. Rennel), Dave.Bates@bris.ac.uk (D.O. Bates)..

$\mathrm{f}_{\text {Cancer Research UK Development Grant A5047. }}$

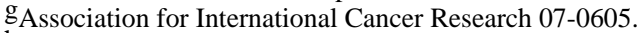

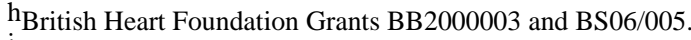

${ }^{i}$ National Kidney Research Fund Grant R15/2/2003.

Conflict of interest statement

Prof. Bates and Dr. Harper are co-inventors on the patent describing VEGF165b as a potential therapeutic in cancer. There are no other conflicts of interest.
} 


\section{Introduction}

Vascular endothelial growth factor-A (VEGF) is the principal angiogenic promoter in most, if not all, cancers. VEGF is upregulated by hypoxia, 1 and by over-expression of oncogenes in tumours, 2 and stimulates the migration of endothelial cells, sprouting of blood vessels and generation of new vessels from existing vasculature in tumours (reviewed in3), resulting in sustained blood flow, oxygen supply and waste removal to the growing tumour. Anti-VEGF therapy has been hailed as the fourth line of cancer treatment alongside surgery, chemotherapy and radiotherapy, and antibodies to VEGF have shown clinical benefit in colorectal cancer, renal carcinoma, non-small cell lung cancer, breast cancer4,5 and are in further phase III clinical trials in other cancers.

VEGF is generated as multiple isoforms by alternative splicing of mRNA from 8 exons. Alternate splicing of exons 6 and 7 results in proteins with differing heparin binding affinity, and numbers of amino acids, such as $\mathrm{VEGF}_{165}, \mathrm{VEGF}_{121}$ and $\mathrm{VEGF}_{189}$, termed according to the number of amino acids encoded in the final secreted protein. Alternate splicing into the terminal exon, exon 8, gives rise to two families of isoforms, the $\mathrm{VEGF}_{\mathrm{xxx}} \mathrm{b}$ and $\mathrm{VEGF}_{\mathrm{xxx}}$ isoforms. The $\mathrm{VEGF}_{\mathrm{xxx}} \mathrm{b}$ family of isoforms, first identified in 2002,6 are generated by the use of a more distal $3^{\prime}$ splice acceptor site, and result in mRNA species that code for proteins of the same length as the $\mathrm{VEGF}_{\mathrm{xxx}}$ isoforms, but with different C-terminal six amino acids. Whereas the $\mathrm{VEGF}_{\mathrm{xxx}}$ isoforms (e.g. $\mathrm{VEGF}_{165}$ and $\mathrm{VEGF}_{121}$ ) are proangiogenic and are upregulated in tumours, the $\mathrm{VEGF}_{\mathrm{xxx}} \mathrm{b}$ isoforms (e.g. $\mathrm{VEGF}_{165} \mathrm{~b}$ and $\mathrm{VEGF}_{121} \mathrm{~b}$ ) are anti-angiogenic and downregulated in tumours.6,7 This anti-angiogenic activity is generated by receptor binding, 7,8 but only weak receptor activation, and inhibition of downstream VEGFR2 signalling.7 Its activity has led to the hypothesis that VEGF $_{165}$ b may be a useful therapeutic tool in angiogenic conditions such as in tumour growth, or in neovascularisation associated with retinopathy9 such as in diabetes.

To determine whether $\mathrm{VEGF}_{165} \mathrm{~b}$ has an appropriate pharmacokinetic profile for systemic anti-angiogenic therapy, we have investigated the clearance rates, toxicity, tumour uptake and circulating effects on blood pressure of $\mathrm{VEGF}_{165} \mathrm{~b}$ injection in mice, and whether recombinant human $\mathrm{VEGF}_{165} \mathrm{~b}$ exerts inhibitory effects on tumour growth in tumourbearing mice.

\section{Materials and methods}

\subsection{Production of recombinant protein}

Recombinant human VEGF $_{165}$ b (rhVEGF 165 b), produced in Chinese Hamster Ovary Cells with correct glycosylation, dimerisation and receptor binding, was generated by Cancer Research Technologies, London, United Kingdom or PPS, Israel. Protein was analysed by MALDI-TOF mass spectrometry (Voyager DE-STR, Applied Biosystems, Foster City, CA). Endotoxins were removed by phase separation using Triton X-114 followed by endotoxin detection using Limulus Amebocyte Lysate performed by Cambrex (Cambrex Corporation). All the proteins were considered endotoxin free (endotoxin levels below $5 \mathrm{EU} / \mathrm{ml}$ of concentrated stock). Recombinant canine $\mathrm{VEGF}_{165}\left(\mathrm{rcVEGF}_{165}\right)$ or $\mathrm{rcVEGF}_{165} \mathrm{~b}$ was produced and assayed for retained activity as previously described.8

\subsection{Functional effects of recombinant VEGF $165 \mathrm{~b}$}

Human umbilical vein endothelial cells (HUVEC) were extracted from umbilical cords from caesarean sections (St. Michael's Hospital, Bristol, UK). HUVECs were maintained in M200 supplemented with low serum growth factor supplements (Cascade Biologics, Portland, OR) in flasks coated with extracellular matrix proteins. Cells were used at passages 3-5. Sub-confluent HUVECs were serum starved for $7 \mathrm{~h}$ in M200 medium without 
supplement, and 100,000 serum starved cells were plated into collagen-coated $8 \mu \mathrm{m}$ inserts (Millipore, Billerica, MA). Inserts were placed in 24-well plates with $500 \mu \mathrm{l}$ of chemoattractant in M200 medium with $0.1 \% \mathrm{v} / \mathrm{v}$ FCS and $0.2 \% \mathrm{w} / \mathrm{v}$ BSA and incubated overnight at $37{ }^{\circ} \mathrm{C}$ to allow for migration. After incubation, inserts were washed, nonmigrated cells were removed and migrating cells were stained in Mayer's haematoxylin. Migrating cells were counted (10 fields per insert) and expressed either as a relative change to basal migration (media without chemoattractant) or\% migration and plotted as average \pm s.e.m. Experiments were performed in triplicate.

To determine the concentration at which $50 \%$ of the migratory response was inhibited, $\left(\mathrm{IC}_{50}\right)$, increasing amounts of $\mathrm{VEGF}_{165} \mathrm{~b}$ were added (1-100 $\left.\mathrm{ng} / \mathrm{ml}\right)$ with or without the optimal concentration of $40 \mathrm{ng} / \mathrm{ml}$ of $\mathrm{VEGF}_{165}$. For stability tests, recombinant $\mathrm{VEGF}_{165} \mathrm{~b}$ was incubated under sterile conditions at $37^{\circ} \mathrm{C}$ for 1 or 2 weeks, whereafter the retained inhibitory migratory response was assayed.

\subsection{Angiogenesis assay}

Extracellular matrix gel solution was prepared according to manufacturer's instructions (Chemicon International, Temecula CA). Thirty microlitre gel solution was transferred to each well of pre-cooled 8-well culture slides (Falcon, BD, Oxford, Oxfordshire, UK) and incubated at $37^{\circ} \mathrm{C}$ to solidify. $\mathrm{VEGF}_{165}, \mathrm{VEGF}_{165} \mathrm{~b}$ and the combination were placed on one side of the gel to $1 \mathrm{nM}$ final concentration. Human Microvascular Endothelial Cells, HMVEC, were serum starved for $3 \mathrm{~h}$ with EBM-2 (Clonetechs, Lonza), and 10,000 cells were seeded onto the gel in $100 \mu \mathrm{lEBM}-2$ basal media and incubated at $37{ }^{\circ} \mathrm{C}$ for $6 \mathrm{~h}$. Gels were fixed in $4 \% \mathrm{w} / \mathrm{v}$ para-formaldehyde/PBS $\mathrm{pH} 7.4$ for $5 \mathrm{~min}$ and washed twice with PBS. F-actin fibres were stained with Alexa 488 phalloidin for $1 \mathrm{~h}$ (Molecular Probes, dilution 1:200 in PBS/0.5\% v/v Triton) and 10 min with Hoechst 33342 (5 $\mu \mathrm{g} / \mathrm{ml} \mathrm{PBS} / 0.5 \%$ v/v Triton). Gels were washed twice with PBS/0.5\% v/v Triton, twice with PBS and mounted with vectashield (Vector Laboratories Burlingame, CA). Images were taken on a Leica DM $\mathrm{RB}$ fluorescence microscope for structure analysis counting branch points, sprouts and closed polygons over the entire area of the well.

\subsection{Injections of recombinant human VEGF ${ }_{165}$ b into LS174t tumour-bearing mice}

LS174t colon carcinoma cells $\left(2 \times 10^{6}\right)$ in $200 \mu 1$ sterile PBS were injected into the nape of the neck of nude mice and injected with rhVEGF 165 b subcutaneously every day or twice weekly (in $200 \mu 10.9 \% \mathrm{w} / \mathrm{v} \mathrm{NaCl}$ ), starting $24 \mathrm{~h}$ after the injection of tumour cells (prophylactic) or when tumours reached a diameter of 4-5 $\mathrm{mm}$ (therapeutic). Bi-weekly intraperitoneal injection was carried out in mice $4 \mathrm{~d}$ after the injection of $2 \times 10^{6} \mathrm{LS} 174 \mathrm{t}$ tumour cells as above. Xenotransplanted tumours were measured by calliper every day, and tumour volume was calculated according to (length $\times$ width $\times[$ length + width $] / 2$ ). Mice were culled by cervical dislocation and organs and tumours were removed. Tumour vessel density was counted in 10 random fields (magnification 40x) in haematoxylin and eosin stained $6 \mu \mathrm{m}$ frozen sections from tumours. Vessel presence was confirmed by staining by blocking in 5\% v/v goat Ig for $30 \mathrm{~min}, 2 \mu \mathrm{g} / \mathrm{ml} \mathrm{PECAM-1}$ antibody (Santa Cruz, sc-1505) or $1 \mu \mathrm{g} / \mathrm{ml} \mathrm{Flk-1} \mathrm{(Santa} \mathrm{Cruz} \mathrm{sc-6251)} \mathrm{overnight,} 2 \mu \mathrm{g} / \mathrm{ml}$ anti-goat or anti-mouse biotin antibody (Vector Laboratories) for $1 \mathrm{~h}$ followed by avidin-biotinylated enzyme complex (ABC, Vector Laboratories) for 30 min followed by DAB substrate (Vector Laboratories). Sections were examined using a Nikon Eclipse E400 microscope and photos were captured using Nikon Eclipse Net software. Area of necrosis was scored in similar way as above by circling necrotic area, calculated from the lighter staining pattern of the haematoxylin and eosin, compared to whole tumour area using Open Lab. 


\subsection{Animal injections and collection of samples}

C57/B16 mice (body weight $>20 \mathrm{~g}$ ) were kept on a heating mat under anaesthesia using 500 $\mu \mathrm{g} / \mathrm{kg}$ medetomidine hydrochloride (Domitor, Pfizer, Tadworth, Surrey, UK) and $50 \mathrm{mg} / \mathrm{kg}$ ketamine (Vetalar V, Pharmacia, Tadworth, Surrey, UK) for intravenous injection and cardiac puncture according to UK Home Office regulations. Local anaesthetic cream (EMLA, Astra Zeneca, Macclesfield, Cheshire, UK) was added to the tail when collecting blood from the tail vein, and each mouse was bled $(\max 100 \mu \mathrm{l})$ only once every $24 \mathrm{~h}$. For each time point at least 3 mice were used and for experiments less than $24 \mathrm{~h}$, multiple mice groups were used with 3 mice in each group. During intraperitoneal and subcutaneous injections, mice were not anaesthetised but monitored for discomfort and pain. Blood was collected under general anaesthesia, as above either through the tail vein or through cardiac puncture into EDTA vacutainers (BD, Oxford, Oxfordshire, UK) and centrifuged at 3,000 rpm at $4{ }^{\circ} \mathrm{C}$ for $10 \mathrm{~min}$, and plasma was transferred to a fresh tube and stored at $-20^{\circ} \mathrm{C}$.

Mini pumps (Alzet, Kent, UK) with infusion rate of $208 \mathrm{ng} / \mathrm{h}(5 \mu \mathrm{g} / 24 \mathrm{~h}$ ) for $14 \mathrm{~d}$ were implanted subcutaneously into C57/B16 mice under isofluorane anaesthesia. Mice were then sutured using Mersilk 6.0 (Ethicon, Johnson-Johnson, Ascot, Berkshire, UK). Mice were given an intramuscular injection of $50 \mu \mathrm{g} / \mathrm{kg}$ Temgesic (Schering-Plough, Hertfordshire, UK). Recombinant protein was diluted in sterile $0.9 \% \mathrm{w} / \mathrm{v} \mathrm{NaCl}$, and injection volumes were 100-200 $\mu \mathrm{l}$ as appropriate for the injection site. Mice were culled by cervical dislocation or exsanguinated under anaesthesia and organs were removed and snap-frozen in liquid nitrogen.

\subsection{ELISA for $\mathrm{VEGF}_{165}$ b or VEGF $\mathrm{V}_{165}$ in plasma}

An in-house ELISA specific for $\mathrm{VEGF}_{165}$ b has been developed and described elsewhere.7 All the reagents were from R\&D Systems (Abingdon, Oxfordshire, UK) if not otherwise stated. Briefly, immulon 2HB 96-well plates (Thermo Scientific, Basingstoke, UK) were coated with $0.8 \mu \mathrm{g} / \mathrm{ml}$ goat anti-hVEGF capture antibody and blocked with $5 \%$ w/v BSA followed by the addition of samples. Detection was done by the addition of biotinylated mouse monoclonal anti-VEGF $165 \mathrm{~b}$ antibody at $0.4 \mu \mathrm{g} / \mathrm{ml}$ followed by incubation with horseradish peroxidase-conjugated streptavidin and substrate development before being read at $450 \mathrm{~nm}$ and $570 \mathrm{~nm}$ for reference.

For rhVEGF $165, \mathrm{rcVEGF}_{165}$ and $\mathrm{rcVEGF}_{165} \mathrm{~b}$, a commercial panVEGF ELISA was used according to manufacturer's protocol (Duoset VEGF ELISA, R\&D Systems, Minneapolis, $\mathrm{MN})$. Plasma samples were diluted 1:10 and run in duplicates or triplicates.

\subsection{In vivo imaging of ${ }^{125}$ I-rhVEGF $_{165}$ b biodistribution}

Nude mice were injected with LS174t tumours on the right hindleg. ${ }^{125}$ I-rhVEGF $_{165}$ b was generated using Iodogen ${ }^{\mathrm{TM}}$ tubes (Pierce Biotechnology Inc.) and purified with NAP-10 columns (GE Healthcare). Analysis by thin layer chromatography revealed $>95 \%$ purity. ${ }^{125} \mathrm{I}_{\text {-rhVEGF }} 165 \mathrm{~b}\left({ }^{125} \mathrm{I}_{\text {-rhVEGF }}\right.$ $_{165} \mathrm{~b} /$ total $\left.^{125} \mathrm{I}\right) .3 .2 \mathrm{MBq}(70 \mu \mathrm{g}$ protein $)$ was injected into the tail vein when tumours were $>10 \mathrm{~mm}$ in diameter. Anaesthesia was maintained by $2 \%$ halothane during X-ray and scanning (NanoSPECT/CT, Bioscan, Washington, DC), after 40, 70, 120, 240 or $1440 \mathrm{~min}$. For biodistribution studies, 0.100 $\mathrm{MBq}(3 \mu \mathrm{g}){ }^{125} \mathrm{I}_{-} \mathrm{rhVEGF}_{165} \mathrm{~b}$ was injected into the tail vein, and mice were culled at 120 or $240 \mathrm{~min}$. Organs and tissues of interest were excised and assessed using a gamma counter (LKB Wallac 1282 Compugamma CS, Wallac). Uptake was expressed as\% injected dose/g tissue. 


\subsection{Toxicology analysis}

Snap-frozen livers from nude mice injected daily with 5 or $10 \mu$ VEGF $_{165}$ b for $14 \mathrm{~d}$ were embedded into O.C.T. compound (Sakura Finetek, Zoeterwoude, Netherlands), and $6 \mu \mathrm{m}$ cryosections were fixed in ice-cold methanol and stained using conventional haematoxylin and eosin staining.

Liver enzyme function was analysed in plasma from C57/B16 mice daily injected with $5 \mu \mathrm{g}$ VEGF $_{165} \mathrm{~b} 0.9 \% \mathrm{w} / \mathrm{v}$ saline (vehicle control) for $8 \mathrm{~d}$. Plasma was collected and analysed by Langford Veterinary Diagnostics, Bristol, UK, for liver enzyme activity (ALT = alanine transaminase, $\mathrm{ALP}=$ alkaline phosphatase and GGT = gamma glutamyl transpeptidase).

\subsection{SDS-PAGE and immunoblotting of tissue and cell lysate}

Tissue lysate from mouse organs or cells was extracted using RIPA buffer (50 mM Tris, 150 $\mathrm{mM} \mathrm{NaCl}, 1 \%$ v/v NP-40, 0.25\% w/v Na-deoxycholate, $1 \mathrm{mM}$ EDTA, $1 \mathrm{mM}$ phenylmethylsulphonyl fluoride, $1 \mu \mathrm{g} / \mathrm{ml}$ of each of aprotinin, pepstatin and leupeptin) and homogenised using a polytron and spun at $12,000 \mathrm{rpm}$ for $10 \mathrm{~min}$ at $4{ }^{\circ} \mathrm{C}$. Lysates were separated on 7.5 or $15 \%$ SDS-PAGE, transferred to polyvinylidene fluoride membranes, blocked in $10 \% \mathrm{w} / \mathrm{v}$ dry milk, incubated with a biotinylated mouse monoclonal anti-human $\mathrm{VEGF}_{165} \mathrm{~b}$ antibody $(0.5 \mu \mathrm{g} / \mathrm{ml})$ followed by horseradish peroxidase-conjugated streptavidin (1/500, R\&D Systems), $200 \mathrm{ng} / \mathrm{ml} \mathrm{Flt-1} \mathrm{antibody} \mathrm{(Santa} \mathrm{Cruz,} \mathrm{sc-316-G)} \mathrm{and} 2$ ng/ml antigoat HRP-conjugated antibody or 1:1000 VEGFR-2 antibody (Cell Signalling \#2479) and 2 $\mathrm{ng} / \mathrm{ml}$ anti-rabbit HRP-conjugated antibody for $1 \mathrm{~h}$ each. Membranes were developed using supersensitive West Femto Maximum Sensitive Substrate (Pierce Biotechnology, Cramlington, Northumberland).

\subsection{Blood pressure measurement}

C57/B16 mice (>20 g) were deeply anaesthetised with sodium pentobarbitone ( $80 \mathrm{mg} / \mathrm{kg}$, i.p.) and maintained airflexic throughout. The left external jugular vein was cannulated for supplementary anaesthetic $(20-25 \mathrm{mg} / \mathrm{kg} / \mathrm{h}$, i.v.) and trachea intubated for maintenance of the airways. The left carotid artery was cannulated to allow blood pressure monitoring. Core body temperature $\left(36-37^{\circ} \mathrm{C}\right.$ ) was maintained throughout by means of a heating blanket connected to a rectal temperature probe, via an automatic feedback control unit. Following a period of time to allow blood pressure stabilisation, saline (vehicle, $100 \mu \mathrm{l}$ ) or rhVEGF $165^{\mathrm{b}}$ $(5 \mu \mathrm{g} / 100 \mu \mathrm{l})$ was infused through the external jugular vein and effects on blood pressure were monitored continuously.

\subsection{Statistical analysis}

Statistical analysis was performed using GraphPad Prism software (version 3.0cx). Data are given as means \pm s.e.m. or mean $\pm 95 \%$ confidence interval when stated. Half-lives were compared using 95\% confidence intervals. One-way ANOVA followed by Bonferroni posthoc test was used to compare migration, liver enzyme levels, tumour weight and structure formations. Unpaired $t$-test and non-linear regression were used for $k$-values, vessel density and $\mathrm{IC}_{50}$ calculation. One or two-way ANOVA was used to compare tumour growth in mice.

\section{Results}

\subsection{Pharmacokinetic studies of circulating VEGF ${ }_{165}$ b}

Recombinant $\mathrm{VEGF}_{165} \mathrm{~b}$ protein produced in $\mathrm{CHO}$ cells resulted in dimerisation and glycosylation of the protein (see Fig. 1A). The functionality of the protein was tested by $\mathrm{VEGF}_{165} \mathrm{~b}$-inhibition of $\mathrm{VEGF}_{165}$-mediated human umbilical vein endothelial cells 
(HUVEC) migration. Fig. 1B shows the migrated cells (relative to serum starved controls) induced under increasing concentrations of $\mathrm{VEGF}_{165} \mathrm{~b}$ in the presence of $40 \mathrm{ng} / \mathrm{ml} \mathrm{VEGF}_{165}$ $(40 \mathrm{ng} / \mathrm{ml}=1 \mathrm{nM}) . \mathrm{VEGF}_{165} \mathrm{~b}$ inhibited migration in a dose-dependent manner with an $\mathrm{IC}_{50}$ of approximately $1 \mathrm{nM}\left(\log \mathrm{IC}_{50}=-9.00 \pm 0.18, \log\right.$ mean $\pm 95 \%$ confidence interval, see Fig. 1B), similar to that observed with commercially produced protein or conditioned media. 6,7 The produced $\mathrm{VEGF}_{165} \mathrm{~b}$ was stable, as incubation at $37^{\circ} \mathrm{C}$ for two weeks did not alter the protein concentration or affect its activity (see Fig. 1C and inserted blot).

\subsection{Pharmacokinetics and biodistribution}

The pharmacokinetic parameters of $\mathrm{VEGF}_{165} \mathrm{~b}$ were compared with conventional $\mathrm{VEGF}_{165}$. To analyse circulating levels of $\mathrm{VEGF}_{165} \mathrm{~b}$, mice were injected with recombinant protein, and plasma was collected at different time points and analysed by ELISA. Intravenous injections of $\mathrm{rcVEGF}_{165} \mathrm{~b}$ into the tail vein of mice showed that $\mathrm{VEGF}_{165} \mathrm{~b}$ (see Fig. 2A) had a circulating plasma half-life of $13 \mathrm{~min}$, which was not significantly different from that for rcVEGF $_{165}$ (see Fig. $2 \mathrm{~A}$, VEGF 165 versus $\mathrm{VEGF}_{165} \mathrm{~b}, p=0.57$, two-tailed Student's $t$-test). $\mathrm{VEGF}_{165} \mathrm{~b}$ was not detectable in the kidney after i.v. injection indicating that the removal from the plasma was not through excretion in the urine (data not shown), and therefore suggesting tissue uptake as the primary destination of the injected protein. Intraperitoneal (i.p. see Fig. 2B) or subcutaneous (s.c., see Fig. 2C) injection of $5 \mu \mathrm{g} \mathrm{rhVEGF} 165$ b led to detectable levels of recombinant protein within $1 \mathrm{~h}$ after injection with a half-life of $4.0 \mathrm{~h}$ (i.p.) or $6.2 \mathrm{~h}$ (s.c.). Clearance rates of $\mathrm{VEGF}_{165}$ b were compared with $\mathrm{VEGF}_{165}$. Injection of $\mathrm{VEGF}_{165}$ or $\mathrm{VEGF}_{165}$ b showed no significant difference when delivered i.p. (see Fig. 2B, $\mathrm{VEGF}_{165}$ versus $\mathrm{VEGF}_{165} \mathrm{~b}, \mathrm{p}=0.88$, two-tailed Student's $t$-test). Repeated s.c. injections every $24 \mathrm{~h}$ did not lead to accumulation of recombinant protein in the plasma (data not shown). A slow release of $\mathrm{VEGF}_{165} \mathrm{~b}$ through infusion from an osmotic mini pump $(0.25 \mu \mathrm{l} /$ $\mathrm{h}, 5 \mu \mathrm{g} / 24 \mathrm{~h}$ ) did not lead to accumulation of $\mathrm{VEGF}_{165} \mathrm{~b}$ in the plasma, and no adverse effects were observed with this infusion of $\mathrm{VEGF}_{165} \mathrm{~b}$ (data not shown).

\subsection{Biodistribution of intravenous VEGF ${ }_{165} \mathrm{~b}$}

To determine how intravenously injected $\mathrm{VEGF}_{165} \mathrm{~b}$ was distributed in vivo, ${ }^{125} \mathrm{I}$ $\mathrm{rhVEGF}_{165} \mathrm{~b}$ was injected intravenously into tumour-bearing mice and imaged using highresolution single photon emission computed tomography (NanoSPECT/CT). Radiolabelled VEGF $_{165} \mathrm{~b}$ was distributed quickly through the mouse and images acquired at $40 \mathrm{~min}$ postinjection showed accumulation in the organs of metabolism and secretion. Thereafter, the overall signal gradually declines due to deiodination of the radiolabelled protein. Fig. 3A-C show whole body transverse, coronal and sagittal sections through the tumour acquired by 70 min post-injection. Uptake of radioactivity can be seen in the tumour as well as in the abdominal tissues such as liver and intestines; however, the image is dominated by accumulation of radioiodine into the thyroid, stomach and bladder indicating rapid dissociation of the radiolabelled iodine attached to the $\mathrm{VEGF}_{165} \mathrm{~b}$. This was confirmed by the analysis of urine which showed that only $10 \%$ of the activity was retained by a $10 \mathrm{kDa}$ cut-off dialysis column, indicating that most of the excreted radioiodine was not proteinbound. In contrast, the proportion of low molecular weight iodine in tumours was similar to that in plasma (50\%, data not shown). Collection of tumour and other tissues and measurement of biodistribution indicated that approximately $6 \%$ of the total ${ }^{125} \mathrm{I}_{-V^{-}} \mathrm{VGF}_{165} \mathrm{~b}$ was found in the tumour at $4 \mathrm{~h}$ and was still detectable at $24 \mathrm{~h}$ (see Fig. 3D). Of the nonsecretory organs, liver showed the highest uptake at $4 \mathrm{~h}$.

\subsection{Recombinant VEGF 165 b reduces tumour growth}

We have previously shown that over-expression of $\mathrm{VEGF}_{165} \mathrm{~b}$ reduces tumour growth in at least five different tumour types $7,10,11$, but $\mathrm{VEGF}_{165} \mathrm{~b}$ expression does not directly affect proliferation or apoptosis of LS174t cells.7 To determine whether recombinant human 
VEGF $_{165}$ b inhibits tumour growth, LS174t colon carcinoma tumour cells were implanted subcutaneously into nude mice and $\mathrm{rhVEF}_{165} \mathrm{~b}$ was injected s.c. daily (see Fig. 4). Daily s.c. injection of $5 \mu \mathrm{g} \mathrm{rhVEGF} 165 \mathrm{~b}$ reduced tumour growth compared with saline injections (vehicle) (see Fig. 4A, $p<0.05$ on day 12, $p<0.01$ on day 13, two-way ANOVA, Bonferroni post-hoc test, $n=6$ per group). The mice did not exhibit any obvious adverse effects from the injections or tumours. Representative images of excised tumours on the day of culling illustrate that vehicle injection (see Fig. 4A, inserted picture) resulted in larger tumours than treatment with $\mathrm{VEGF}_{165} \mathrm{~b}$ (see Fig. 4A, inserted picture). Analysis of tumour weights revealed a trend towards smaller tumours in $\mathrm{VEGF}_{165} \mathrm{~b}$ treated than saline-treated animals (unpaired $t$-test $p=0.08, n=6$ per group, Fig. 4B), and the doubling time of the LS174t tumours treated with $\mathrm{rhVGF}_{165} \mathrm{~b}$ was significantly increased $(p<0.05$, unpaired $t$ test vehicle versus rhVEGF 165 , data not shown).

The excised tumours were sectioned and stained to visualise blood vessel distribution (see Fig 4E for representative CD31/PECAM-1 vessel staining of tumour section). Analysis of the vessel density in 10 random fields in each tumour revealed a decreased number of vessels in rhVEGF $_{165}$ b-treated tumours (control versus rhVEGF $_{165} \mathrm{~b} 24 \mathrm{~h}$ post-injection, 2.9 \pm 0.4 versus $0.9 \pm 0.4, p<0.01$, control versus rhVEGF $_{165}$ b established tumours, $3.2 \pm 0.5$ versus $0.8 \pm 0.1$, unpaired $t$-test, $n=6$ tumours per treatment 10 fields analysed per tumour, Fig. 4D). The level of necrosis was not different in the tumours (control versus $\mathrm{rhVEGF}_{165} \mathrm{~b}$, $29.1 \pm 8.7 \%$ versus $32.3 \pm 9.6 \%, p<0.80$, unpaired $t$-test). VEGFR-2 staining of tumours sections revealed expression of VEGFR-2 in the tumour vessels and not in the general tumour mass (see Fig. 4F-G) indicating an effect of $\mathrm{VEGF}_{165} \mathrm{~b}$ on the endothelium rather than an anti-proliferative effect on the tumour cells. VEGFR-1 expression was also absent from the LS174t cells (see Fig. 4G), and recombinant $V_{E G F}$ 165 b did not affect LS174t cell growth in vitro (Fig. 4H).

To determine whether $\mathrm{VEGF}_{165} \mathrm{~b}$ had a therapeutic role, we measured the effect of treatment of tumours with rhVEGF $_{165} \mathrm{~b}$ on the growth rate of established tumours. Two million colon carcinoma cells (LS174t) were injected subcutaneously into nude mice, and tumours were allowed to grow to a diameter of $4-5 \mathrm{~mm}$ (day 4 ) before daily injection of $\mathrm{rhVEGF}_{165} \mathrm{~b}$ was initiated. Treatment with $\mathrm{rhVEGF}_{165} \mathrm{~b}$ significantly reduced the growth rate in established tumours, and significance was reached on day 15 after $11 \mathrm{~d}$ of treatment $(p<0.05$, one-way ANOVA $n=5$ or 6 , Fig. 4C). Again, sectioning and staining for blood vessels indicated a reduction in microvessel density in the tumours from $\mathrm{VEGF}_{165}$ b-treated mice (see Fig. 4D).

To determine whether $\mathrm{VEGF}_{165} \mathrm{~b}$ administration could reduce tumour growth at longer dosing intervals, we measured the effect of treatment of tumours by subcutaneous injection of $100 \mu \mathrm{g}$ rhVEGF 165 b bi-weekly. Two million colon carcinoma cells (LS174t) were injected subcutaneously into nude mice, and tumours were allowed to grow to a diameter of 4-5 mm (day 4) before bi-weekly subcutaneous injection of $100 \mu \mathrm{g}$ rhVEGF 165 b was initiated. Treatment with $\mathrm{rhVEF}_{165} \mathrm{~b}$ significantly reduced the volume of the established tumours compared with before injection on days 7 and 10 ( $p<0.01$, two-way ANOVA, $p<$ 0.001 , Bonferroni $n=8$, Fig. 5A), and the volumes were significantly smaller than those treated with saline after $10 \mathrm{~d}(p<0.01$, Bonferroni). These data show that subcutaneous injections of recombinant $\mathrm{VEGF}_{165} \mathrm{~b}$ reduce the growth in vivo of heterotopic colon carcinoma tumours.

To determine whether intraperitoneal injection could inhibit tumour growth, two million colon carcinoma cells (LS174t) were injected subcutaneously into nude mice, and tumours were allowed to grow for $4 \mathrm{~d}$ before bi-weekly intraperitoneal injection of rhVEGF $_{165} \mathrm{~b}$ was initiated (Fig. 5B). Treatment with rhVEGF $_{165} \mathrm{~b}$ significantly and dose dependently inhibited the growth of the established tumours compared with saline injection on day 10 for 50,75 
and $100 \mu \mathrm{g} \operatorname{VEGF}_{165} \mathrm{~b}$ ( $p<0.001$, two-way ANOVA, $n=8$, Fig. 5B). The $100 \mu \mathrm{g}$ dose resulted in a significantly greater inhibition of tumour volume on $14 \mathrm{~d}$ than the $75 \mu \mathrm{g}$ dose ( $p<0.001$, two-way ANOVA, $n=8$, Fig. 5B). Analysis of the dose response curve at day 10 showed that the IC50 for the tumour inhibition was $48 \mu \mathrm{g}$.

These results show that injections of recombinant $\mathrm{VEGF}_{165} \mathrm{~b}$ reduce the growth in vivo of heterotopic colon carcinoma tumours.

\subsection{VEGF 165 b reduces spreading and vessel formation of endothelial cells on extracellular matrix}

To explore the effect of $\mathrm{VEGF}_{165} \mathrm{~b}$ on microvascular cells, an in vitro angiogenesis assay was used. Human dermal microvascular cells were seeded on an extracellular matrix gel containing $1 \mathrm{nM} \mathrm{VEGF}{ }_{165}, 1 \mathrm{nM} \mathrm{VEGF}_{165} \mathrm{~b}$, a combination of $1 \mathrm{nM} \mathrm{VEGF}_{165}$ and $1 \mathrm{nM}$ $\mathrm{VEGF}_{165} \mathrm{~b}$ or media without growth factors or serum. As expected, cells stimulated with VEGF $_{165}$ produced extended vessel structures (see Fig. 6A) quantified by increased branch points, sprouting structures and closed polygon structures (see Fig. $6 \mathrm{C}$ ). $\mathrm{VEGF}_{165} \mathrm{~b}$ or the combination of $\mathrm{VEGF}_{165}$ and $\mathrm{VEGF}_{165} \mathrm{~b}$ reduced the cells ability to extend and form structures on the extracellular matrix (see Fig. 6B and C). This further indicates that $\mathrm{VEGF}_{165} \mathrm{~b}$ has a direct effect on the endothelial cells along with reduced migration of HUVECs (see Fig. 1C) and reduction in tumour growth by reduction of the microvessel density (see Fig. 4D).

\subsection{Accumulation and toxicology analysis}

$\mathrm{VEGF}_{165} \mathrm{~b}$ was shown to accumulate in the liver (see Fig. 3D) and to determine whether $V_{E G F} 165$ b had any negative effects on liver function, liver sections from mice receiving i.p. injections daily for 2 weeks were sectioned and stained. No apparent changes were seen in the morphology of the liver sections from mice injected with vehicle compared with mice injected with increasing amount of $\mathrm{VEGF}_{165} \mathrm{~b}$ (see Fig. 7A) even though intact $\mathrm{VEGF}_{165} \mathrm{~b}$ protein was found (see Fig. 7B). Mice were also closely monitored during the injection period by visual inspection, and no changes in behaviour, indications of inflammation or any other unusual observations were apparent. No significant difference was observed in the liver enzyme levels between i.p. $\mathrm{VEGF}_{165} \mathrm{~b}$ injected and vehicle injected mice (see Fig. 7C, $n=3$ mice per enzyme test, $p>0.05$, one-way ANOVA), indicating that $\mathrm{VEGF}_{165} \mathrm{~b}$ had no apparent adverse effects on liver function. Proteinuria was not seen after $100 \mu \mathrm{g}$ bi-weekly i.p. injection (mean \pm SEM urinary protein:creatinine ratios $32.6 \pm 5.49 \mathrm{mg} / \mathrm{mmol}$ control compared with $32.6 \pm 10.2 \mathrm{mg} / \mathrm{mmol} \mathrm{VEGF}_{165} \mathrm{~b}$ ).

VEGF $_{165}$ is known to rapidly induce hypotension after i.v. injection.12 Mice were injected with $5 \mu \mathrm{g} \mathrm{rhVEGF}_{165} \mathrm{~b}$ i.v. and blood pressure was measured. No hypotension was observed (see Fig. 7D).

\section{Discussion}

The anti-angiogenic isoform of VEGF, $\mathrm{VEGF}_{165} \mathrm{~b}$, is a potent inhibitor of blood vessel growth in ocular angiogenesis9 as well as in models of $\mathrm{VEGF}_{165}$-induced angiogenesis.7 $\mathrm{VEGF}_{165} \mathrm{~b}$ levels are high in normal, non-angiogenic tissues, forming a substantial proportion or the majority of VEGF isoforms ( ${ }^{13}$ and unpublished data). This family is downregulated or poorly expressed in angiogenesis-related conditions, both in physiological (e.g. in placenta14) and in pathological angiogeneses such as in tumours6,7, or diabetic retinopathy. 13 As this is an endogenous anti-angiogenic isoform, the principle of restoring the balance of anti- versus pro-angiogenic isoforms in pathologies that are dependent on blood vessel growth is an attractive concept. 
This is the first time recombinant $\mathrm{VEGF}_{165} \mathrm{~b}$ has been shown to inhibit tumour growth and reduce the growth of established colon carcinomas, and it indicates that $\mathrm{VEGF}_{165} \mathrm{~b}$ may have a therapeutic role as an anti-cancer agent. Bi-weekly administration in mice, at doses similar to other anti-angiogenic therapies, is clearly effective. Systemic administration of $V_{E G F} 165$ b will require sufficient protein for tumour accumulation to reach therapeutic values. Previous studies have shown that $\mathrm{VEGF}_{165}$ has a short circulating plasma half-life $(25 \mathrm{~min}$ in mice15, 13.8-72 $\mathrm{min}$ in rats $16,17,18)$ when given as a bolus i.v. injection, consistent with the experiments described here. However, continuous infusion of $\mathrm{VEGF}_{165}$ results in detectable circulating levels after up to $28 \mathrm{~d} 15,17$ Combined with the data described here, showing that the concentration of $\mathrm{VEGF}_{165} \mathrm{~b}$ in the tumour was $6 \%$ of the injected dose, this suggests that the circulating plasma half-life of $\mathrm{VEGF}_{165} \mathrm{~b}$ is less important than the tissue concentration. By using these levels as a guide, the level of $\mathrm{VEGF}_{165} \mathrm{~b}$ that may be required to inhibit tumour growth when given i.v. in humans might be speculated to be at doses of the order of 0.1 to $1.4 \mathrm{mg} \mathrm{kg}^{-1}$ day $^{-1} 17 . \mathrm{VEGF}_{165}$ is known to be found in organs such as liver, kidney, spleen and lungs in humans19 and rats 16 after intravenous or subcutaneous injections, respectively. A previous study with a single i.v. injection of $\mathrm{VEGF}_{165}$ into mice showed undetectable levels after $50 \mathrm{~min}$, but was detected in the liver and kidney as measured by the accumulation of radioactive labelled VEGF 165.15 Despite analysing kidneys and lungs, we only detected accumulation of intact rhVEGF ${ }_{165} \mathrm{~b}$ in the liver. These data suggest that delivery of $\mathrm{VEGF}_{165} \mathrm{~b}$ appears to be safe in animal models, that it is an effective anti-cancer agent and that further optimisation of the dosing strategy may be appropriate to determine the most effective therapeutic regimen in patients.

The current findings indicate that systemic administration of recombinant $\mathrm{VEGF}_{165} \mathrm{~b}$ protein would be an effective therapeutic agent in cancer (e.g. by infusion, or subcutaneous or intraperitoneal injection).

\section{Acknowledgments}

The authors would like to thank Cancer Research Technologies, London, for generation of VEGF 165 b, Leslie Sage for technical assistance and extraction of HUVEC and Dr. Kate Heesom at the Department of Biochemistry, University of Bristol for mass spectrometry. This work was supported by a Cancer Research UK Development Grant (A5047), the British Heart Foundation (BB2000003 and BS06/005) and National Kidney Research Fund Grant R15/2/2003.

\section{REFERENCES}

1. Shweiki D, Itin A, Soffer D, Keshet E. Vascular endothelial growth factor induced by hypoxia may mediate hypoxia-initiated angiogenesis. Nature. 1992; 359(6398):843-5. [PubMed: 1279431]

2. Rak J, Mitsuhashi Y, Bayko L, et al. Mutant ras oncogenes upregulate VEGF/VPF expression: implications for induction and inhibition of tumor angiogenesis. Cancer Res. 1995; 55(20):4575-80. [PubMed: 7553632]

3. Ferrara N. Vascular endothelial growth factor: basic science and clinical progress. Endocr Rev. 2004; 25(4):581-611. [PubMed: 15294883]

4. Hurwitz HI, Fehrenbacher L, Hainsworth JD, et al. Bevacizumab in combination with fluorouracil and leucovorin: an active regimen for first-line metastatic colorectal cancer. J Clin Oncol. 2005; 23(15):3502-8. [PubMed: 15908660]

5. Hurwitz H, Fehrenbacher L, Novotny W, et al. Bevacizumab plus irinotecan, fluorouracil, and leucovorin for metastatic colorectal cancer. New Engl J Med. 2004; 350(23):2335-42. [PubMed: 15175435]

6. Bates DO, Cui TG, Doughty JM, et al. VEGF $165^{b}$, an inhibitory splice variant of vascular endothelial growth factor, is down-regulated in renal cell carcinoma. Cancer Res. 2002; 62(14): 4123-31. [PubMed: 12124351] 


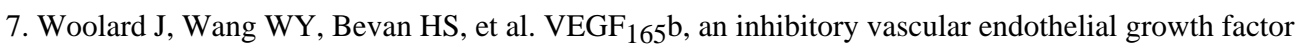
splice variant: mechanism of action, in vivo effect on angiogenesis and endogenous protein expression. Cancer Res. 2004; 64(21):7822-35. [PubMed: 15520188]

8. Cebe Suarez S, Pieren M, Cariolato L, et al. A VEGF-A splice variant defective for heparan sulfate and neuropilin-1 binding shows attenuated signaling through VEGFR-2. Cell Mol Life Sci. 2006; 63(17):2067-77. [PubMed: 16909199]

9. Konopatskaya O, Churchill AJ, Harper SJ, Bates DO, Gardiner TA. VEGF $165^{b}$, an endogenous Cterminal splice variant of VEGF, inhibits retinal neovascularization in mice. Mol Vis. 2006; 12:626-32. [PubMed: 16735996]

10. Varey AH, Rennel ES, Qiu Y, et al. VEGF $165^{\mathrm{b}}$, an antiangiogenic VEGF-A isoform, binds and inhibits bevacizumab treatment in experimental colorectal carcinoma: balance of pro- and antiangiogenic VEGF-A isoforms has implications for therapy. Br J Cancer. 2008; 98(8):1366-79. [PubMed: 18349829]

11. Rennel E, Waine E, Guan H, et al. The endogenous anti-angiogenic VEGF isoform, $\mathrm{VEGF}_{165} \mathrm{~b}$ inhibits human tumour growth in mice. Br J Cancer. 2008; 98(7):1250-7. [PubMed: 18349828]

12. Yang R, Thomas GR, Bunting S, et al. Effects of vascular endothelial growth factor on hemodynamics and cardiac performance. J Cardiovasc Pharmacol. 1996; 27(6):838-44. [PubMed: 8761851]

13. Perrin RM, Konopatskaya O, Qiu Y, Harper S, Bates DO, Churchill AJ. Diabetic retinopathy is associated with a switch in splicing from anti- to pro-angiogenic isoforms of vascular endothelial growth factor. Diabetologia. 2005; 48(11):2422-7. [PubMed: 16193288]

14. Bates DO, MacMillan PP, Manjaly JG, et al. The endogenous anti-angiogenic family of splice variants of VEGF, $\mathrm{VEGF}_{\mathrm{xxx}} \mathrm{b}$, are down-regulated in pre-eclamptic placentae at term. Clin Sci (Lond). 2006; 110(5):575-85. [PubMed: 16451124]

15. Gabrilovich D, Ishida T, Oyama T, et al. Vascular endothelial growth factor inhibits the development of dendritic cells and dramatically affects the differentiation of multiple hematopoietic lineages in vivo. Blood. 1998; 92(11):4150-66. [PubMed: 9834220]

16. Kim TK, Burgess DJ. Pharmacokinetic characterization of 14C-vascular endothelial growth factor controlled release microspheres using a rat model. J Pharm Pharmacol. 2002; 54(7):897-905. [PubMed: 12162707]

17. Yang R, Bunting S, Ko A, et al. Substantially attenuated hemodynamic responses to Escherichia coli-derived vascular endothelial growth factor given by intravenous infusion compared with bolus injection. J Pharmacol Exp Ther. 1998; 284(1):103-10. [PubMed: 9435167]

18. Hsei V, Deguzman GG, Nixon A, Gaudreault J. Complexation of VEGF with bevaczumab decreases VEGF clearance in rats. Pharm Res. 2002; 19(11):1753-6. [PubMed: 12458683]

19. Li S, Peck-Radosavljevic M, Kienast O, et al. Iodine-123-vascular endothelial growth factor-165 (123I-VEGF165). Biodistribution, safety and radiation dosimetry in patients with pancreatic carcinoma. Q J Nucl Med Mol Imaging. 2004; 48(3):198-206. [PubMed: 15499293] 

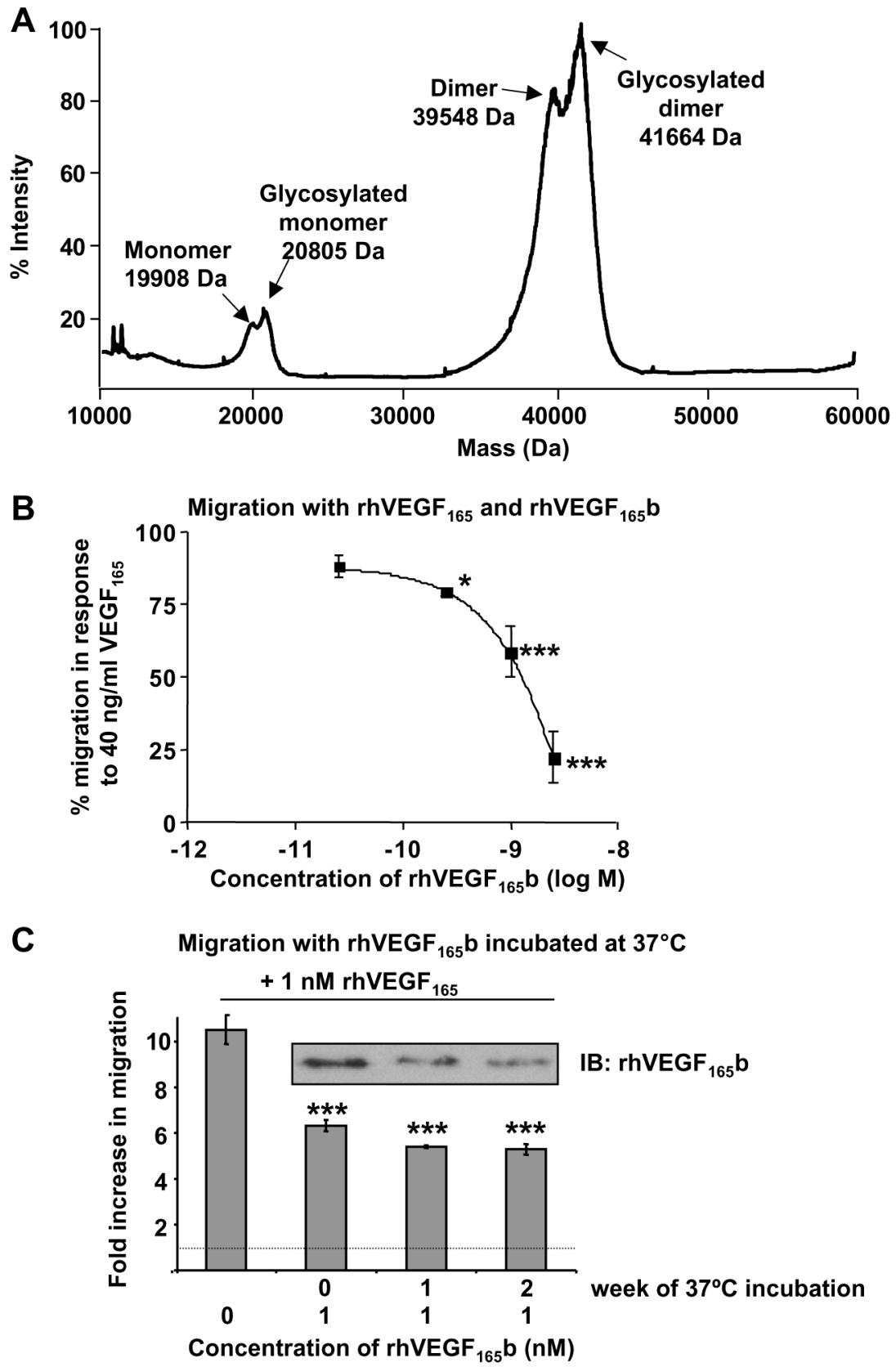

Fig. 1.

Recombinant human $\mathrm{VEGF}_{165} \mathrm{~b}$ is dimeric, glycosylated, thermostable and inhibits rhVEGF $_{165}$-mediated migration in endothelial cells. (A) MALDI-TOF mass spectrometry analysis of recombinant human $\mathrm{VEGF}_{165}$ b produced in $\mathrm{CHO}$ cells and analysed by mass spectrometry showing that the protein forms dimers and is glycosylated. Monomer 19.9 $\mathrm{kDa}$, glycosylated monomer $20.8 \mathrm{kDa}$, dimer $39.6 \mathrm{kDa}$ and glycosylated dimer $41.7 \mathrm{kDa}$. (B) Serum starved human umbilical vein endothelial cells, HUVEC, were allowed to migrate through $8 \mu \mathrm{m}$ pore inserts with increasing concentrations of rhVEGF $165 \mathrm{~b}(0-100 \mathrm{ng} /$ $\mathrm{ml}$ ) in the presence of $40 \mathrm{ng} / \mathrm{ml} \mathrm{rhVEGF}_{165}$ for $18 \mathrm{~h}$. Data plotted as percentage migration compared with no addition of $\operatorname{rhVEGF}_{165}$ b (average \pm SEM, one-way ANOVA $p<0.001$, Bonferroni post-hoc test $\mathrm{VEGF}_{165}$ versus treatment, $* p<0.05$, *** $\left.p<0.001\right) . \mathrm{IC}_{50}$ for 
rhVEGF $_{165}$ b was $1 \mathrm{nM}\left(\log \mathrm{IC}_{50}=-9.00 \pm 0.18, \log\right.$ mean $\pm 95 \%$ confidence interval, nonlinear regression). (C) rhVEGF $_{165} \mathrm{~b}$ was stable for more than two weeks in sterile buffer solution at $37{ }^{\circ} \mathrm{C}$ as confirmed by sustained inhibition of migration and western blot analysis (average \pm SEM, one-way ANOVA $p<0.001$, Bonferroni post-hoc test $\mathrm{VEGF}_{165}$ versus treatment, $* * * p<0.001)$. 

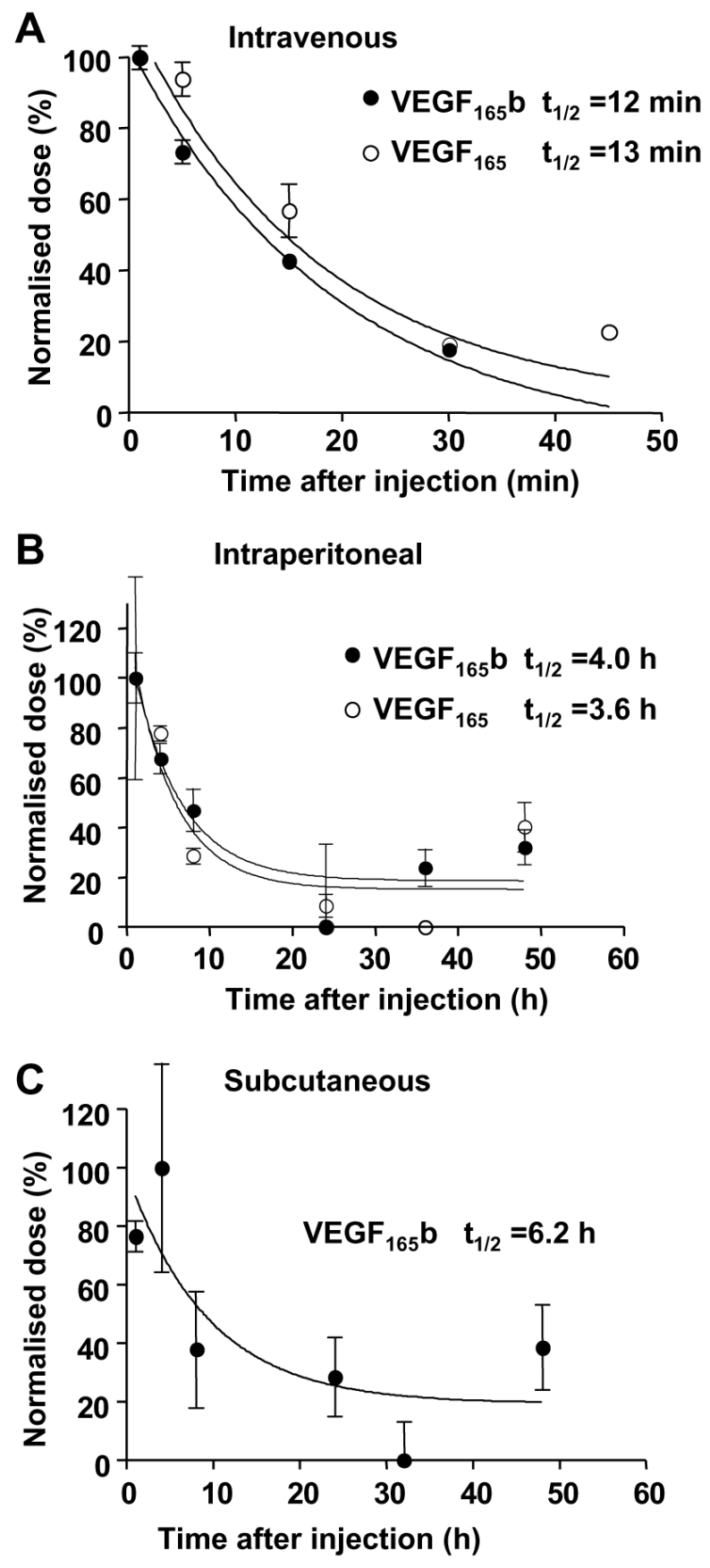

Fig. 2.

$\mathrm{rhVEGF}_{165} \mathrm{~b}$ is cleared at the same rate as $\mathrm{rhVEGF}_{165}$. After a single injection of $5 \mu \mathrm{g}$ of recombinant protein per mouse either through the tail vein (A) intraperitoneal $(B)$, or subcutaneously (C) into mice, blood was collected at different time points. Plasma samples were analysed by ELISA and plotted as normalised concentration (\%). (A) Tail vein injections of recombinant canine $\mathrm{VEGF}_{165}$ or $\mathrm{VEGF}_{165} \mathrm{~b}$ showed no difference in clearance rates $\left(\mathrm{VEGF}_{165}\right.$ versus $\mathrm{VEGF}_{165} \mathrm{~b}, p=0.57$, two-tailed Student's $t$-test). (B) Intraperitoneal injection showed a slower clearance of both the proteins from the circulation. $(\mathrm{C})$ Subcutaneous injection led to the slowest clearance from the circulation of $\mathrm{VEGF}_{165} \mathrm{~b}$. 


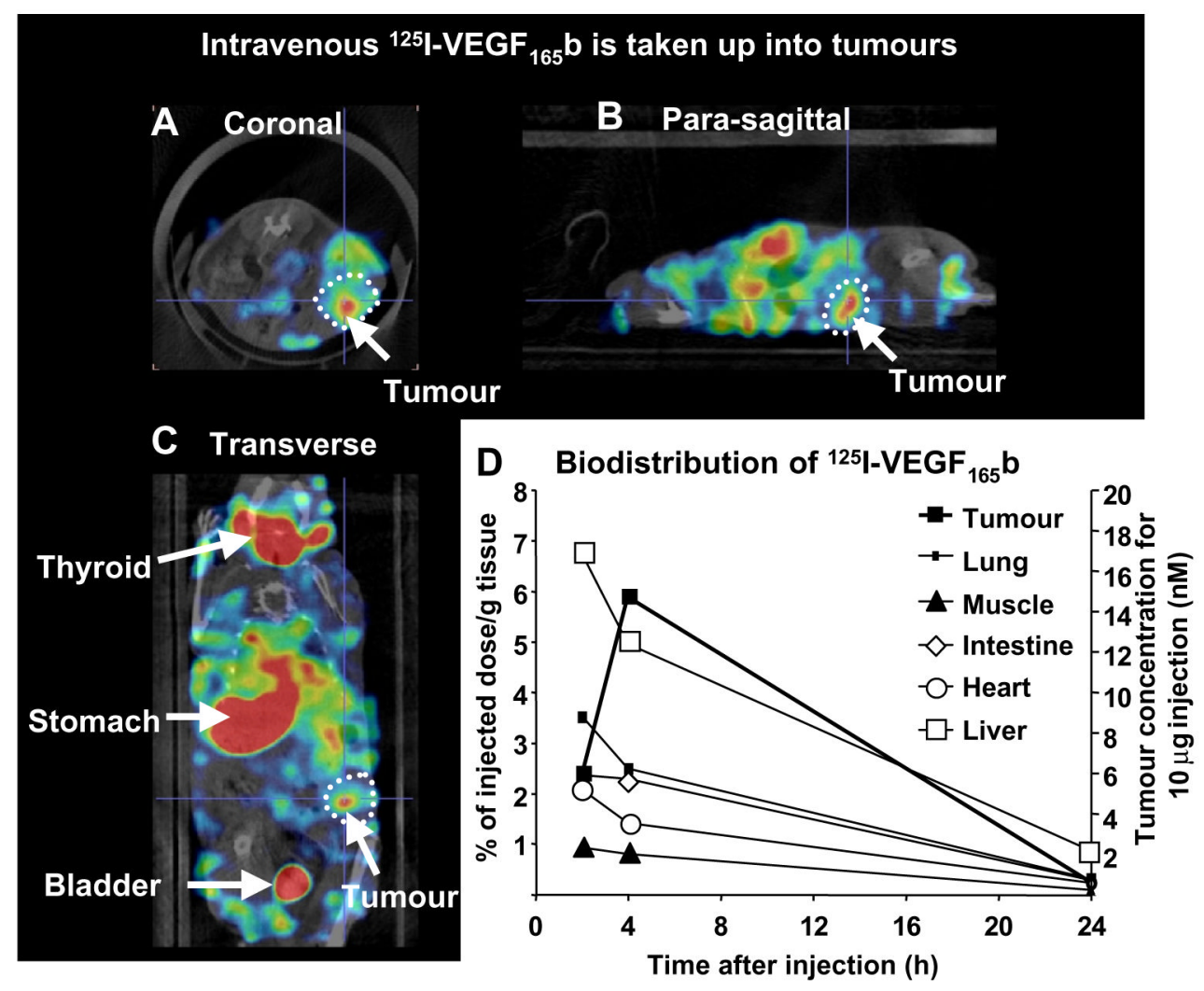

Fig. 3.

In vivo distribution of ${ }^{125} \mathrm{I}_{-\mathrm{rhVEGF}} \mathrm{H}_{165} \mathrm{~b}$. Tumour-bearing mice received an intravenous injection of ${ }^{125} \mathrm{I}_{-} \mathrm{rVEGF}_{165} \mathrm{~b}$ and $3 \mathrm{D}$ imaged using NanoSPECT/CT. (A-C) Coronal, sagittal and transverse sections through the centre of the tumour after 70 min post-injection are shown. The tumour is circled and arrows indicate different organs. (D) Quantification of uptake into different organs and tissues over time. Data expressed as\% in tissue relative to the total injected dose, per gram of tissue, or on the right hand axis the concentration that would be reached in the tumour if the pharmacokinetics were identical for a $10 \mu \mathrm{g}$ intravenous dose of $\mathrm{VEGF}_{165} \mathrm{~b}$. 
A Treatment $24 \mathrm{~h}$ post LS174t implantation

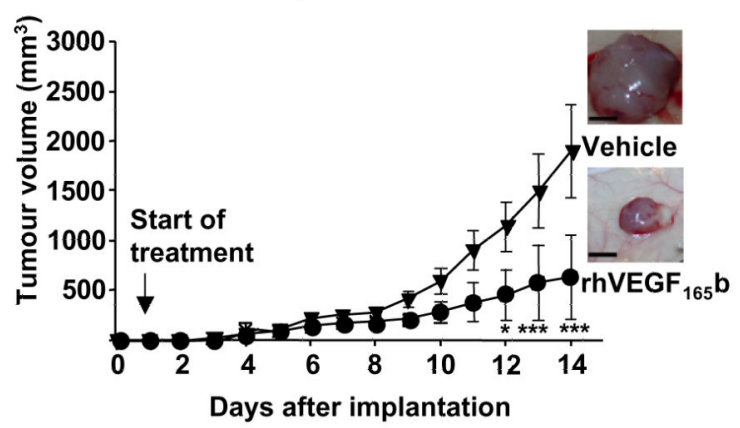

C

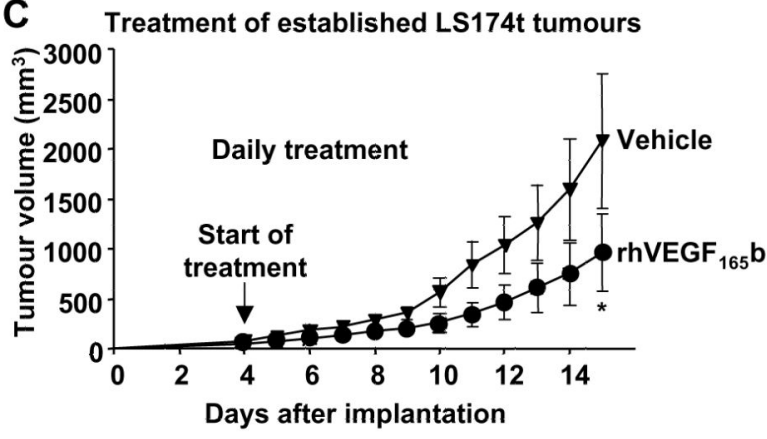

B Tumour weight

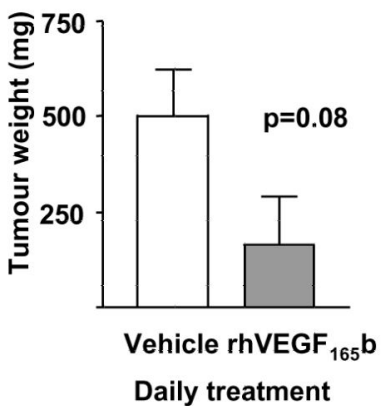

D

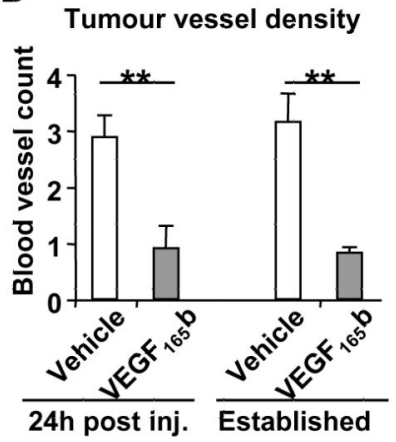

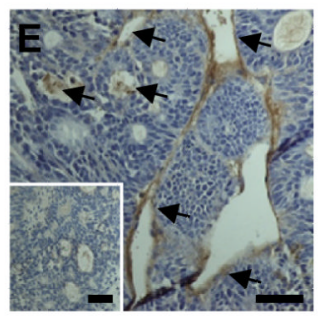
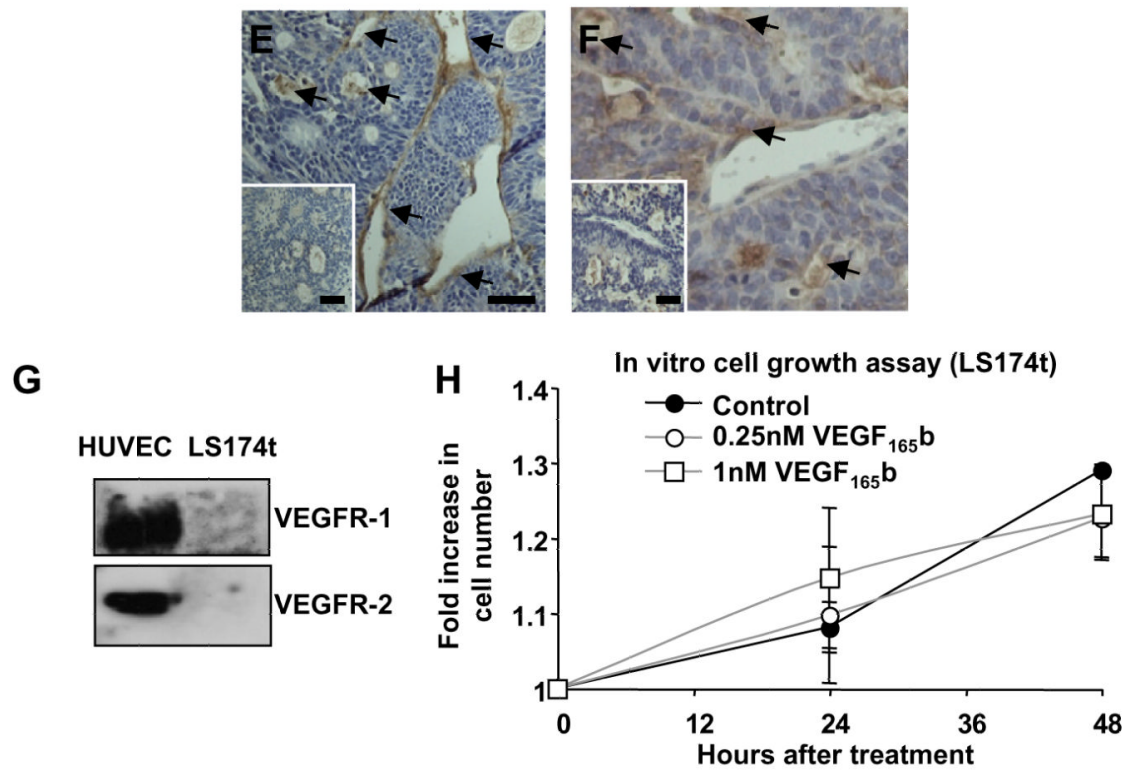

Fig. 4.

Daily subcutaneous injection of $\operatorname{rhVEGF}_{165}$ b reduces tumour growth in nude mice-bearing colon carcinoma tumours. (A) LS174t cells injected subcutaneously resulted in large, bloody tumours when treated daily with saline (inserted picture). Subcutaneous injection of rhVEGF $_{165} \mathrm{~b}$, however, resulted in smaller tumours (inserted picture). (B) Weight of excised tumours, $p=0.08$ unpaired $t$-test, $n=6$ per group. (C) Subcutaneous injection of rhVEGF $_{165}$ b also inhibited established colon carcinoma tumours in nude mice. LS174t colon carcinoma cells were injected subcutaneously and treatment was started when tumours reached 4-5 $\mathrm{mm}$ in diameter (day 4 after implantation). Tumour growth was reduced in mice treated with $5 \mu \mathrm{g} \operatorname{rhVEGF}_{165}$ b compared to vehicle control $(p<0.05$ on day 11 after start of 
treatment, one-way ANOVA). (D) Tumours treated with $\mathrm{VEGF}_{165}$ b showed significantly fewer blood vessels per unit area than control-injected tumours. Each point represents the mean of ten random analysed fields and 6 tumours per treatment were examined $(* * p<0.01$ unpaired $t$-test). (E-F) Immunohistochemistry staining of blood vessels in LS174t tumours using CD31/PECAM-1 (E) or VEGFR2 (F). Arrows indicate staining of the vessels. Inserted images are IgG control showing no non-specific staining. Scale bar $=100 \mu \mathrm{m}$. (G) Western blot illustrating the lack of VEGFR-1 or VEGFR-2 in LS174t cells. (H) 135,000 LS174t cells were treated with control (no $\mathrm{VEGF}_{165} \mathrm{~b}$ ), $0.25 \mathrm{nM}$ or $1 \mathrm{nM} \mathrm{VEGF}_{165} \mathrm{~b}$ and cell number counted with a haemocytometer after 24 or $48 \mathrm{~h}$ treatment. There was no effect of $\mathrm{VEGF}_{165} \mathrm{~b}$ treatment on cell number (expressed relative to starting cell number). 

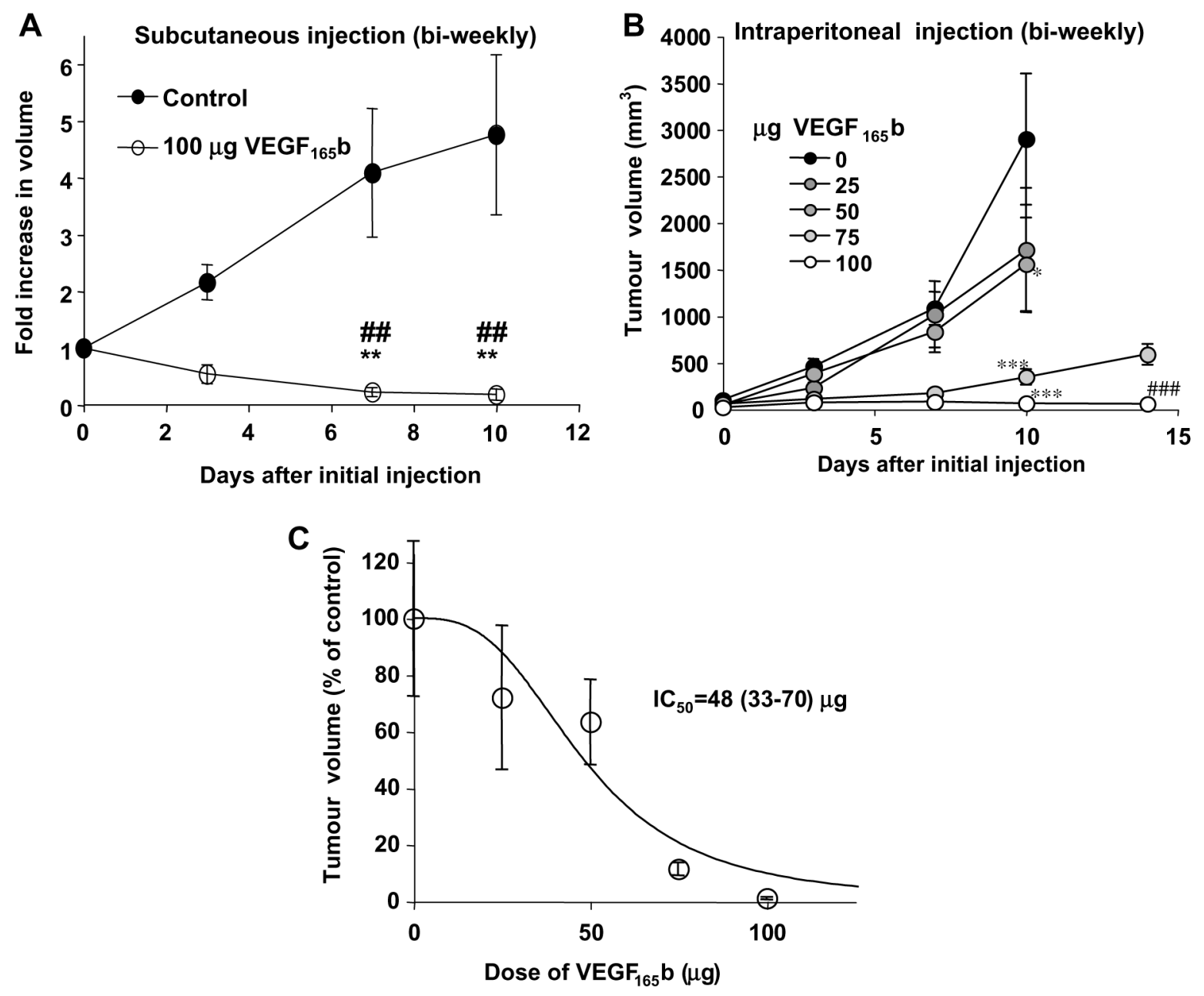

Fig. 5.

Bi-weekly administration of $\mathrm{VEGF}_{165} \mathrm{~b}$ inhibits tumour growth. (A) Subcutaneous injection of $100 \mu \mathrm{g} \mathrm{rhVEGF}{ }_{165} \mathrm{~b}$ bi-weekly resulted in the reduction of volume of established colon carcinoma tumours in nude mice. LS174t colon carcinoma cells were injected subcutaneously and treatment was started when tumours reached 4-5 mm in diameter (day 4 after implantation). $100 \mu \mathrm{g} \mathrm{rhVEGF}_{165} \mathrm{~b}$ reduced tumour volume $(* * p<0.01)$ compared with start of treatment and compared with saline treated (\#\#p<0.01). (B) Intraperitoneal injection of rhVEGF $_{165} \mathrm{~b}$ dose dependently reduced the tumour growth of colon carcinomas in nude mice. LS174t colon carcinoma cells were injected subcutaneously and the treatment was started after $4 \mathrm{~d}$. $\mathrm{VEGF}_{165} \mathrm{~b}$ treatment inhibited tumour growth compared with saline-

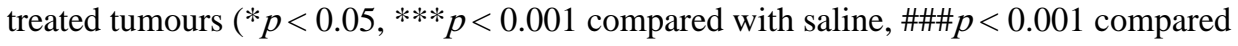
with $75 \mu \mathrm{g}$ on day 14). (C) Dose response curve for inhibition of tumours. The relationship between tumour volume at $10 \mathrm{~d}$ compared with control tumours and dose ( $\mu \mathrm{g}$ bi-weekly) indicated that $\mathrm{VEGF}_{165} \mathrm{~b}$ inhibited tumour growth with a mean (CI) IC50 of 48 (33-70) $\mu \mathrm{g}$. 

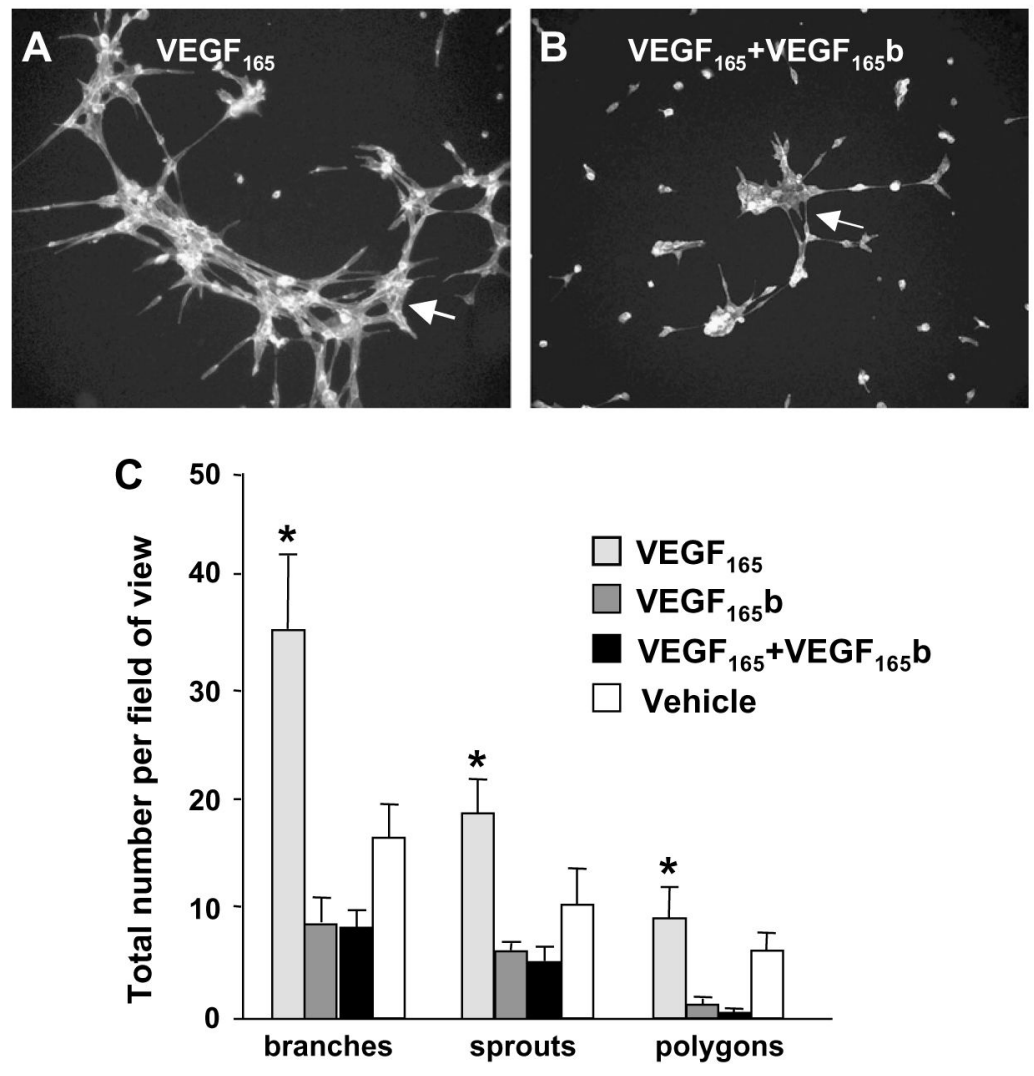

Fig. 6.

VEGF $_{165}$ b reduces vessel structures on matrigel. HMVECs were seeded on top of extracellular matrix gel for $6 \mathrm{~h}$ and F-actin fibres were visualised. Cells underwent extensive structure formation after challenge with $\operatorname{VEGF}_{165}(\mathrm{~A})$ but showed rather poor structures with a combination of $\mathrm{VEGF}_{165}$ and $\mathrm{VEGF}_{165} \mathrm{~b}(\mathrm{~B})$, resulting in a significantly reduced number of structure elements like sprouts, branch points and closed polygons (C). Arrow points towards polygon structures. 
A

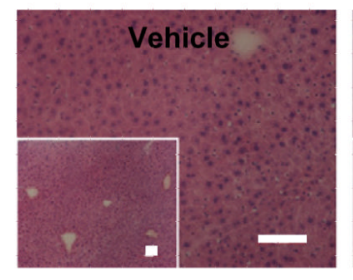

Liver H\&E
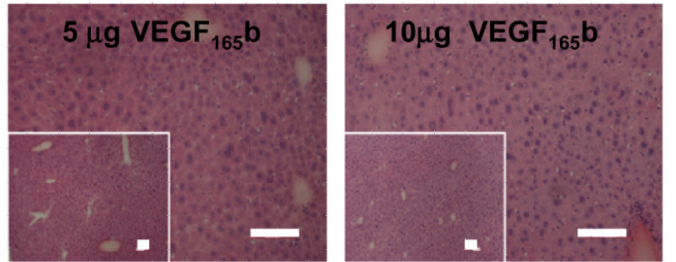

B

$\begin{array}{llllll}0 & 1 & 4 & 8 & 12 & 24\end{array}$

$24 \quad \operatorname{VEGF}_{165}$ (h)

$100 ! \mathrm{m}$
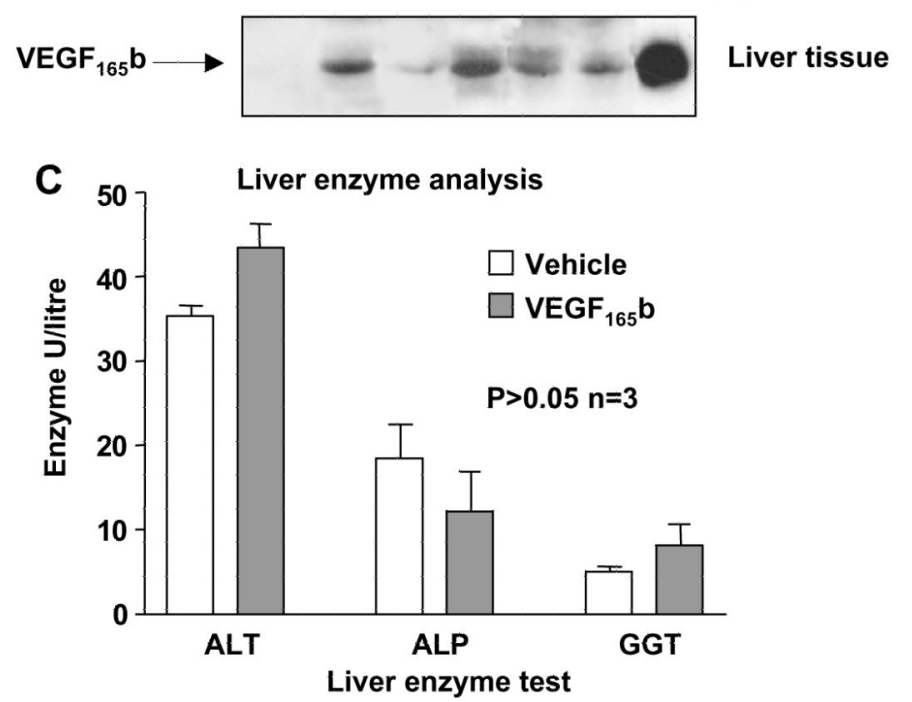

D Blood pressure measurement

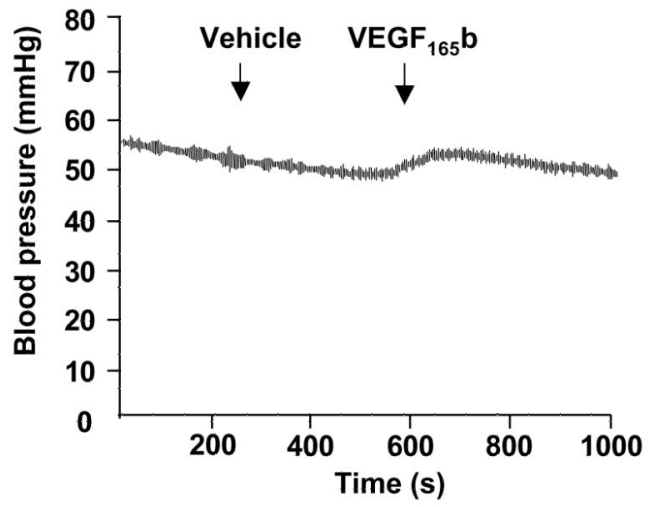

Fig. 7.

No adverse effects of $\mathrm{VEGF}_{165} \mathrm{~b}$ injections. (A) No toxic effects on liver morphology were seen after repeated i.p. injections of $\mathrm{VEGF}_{165} \mathrm{~b}$. Haematoxylin and eosin stained cryosections of livers excised from mice injected daily with saline vehicle, $5 \mu \mathrm{g}$ or $10 \mu \mathrm{g}$ rhVEGF $_{165}$ b for $14 \mathrm{~d}$. No adverse or toxic effects or changes on the liver morphology were observed. Scale bars $=100 \mu \mathrm{m}$. (B) After intraperitoneal injection, the protein accumulated in the liver for the entire time of analysis (24 h). (C) No significant change in liver enzyme levels in plasma from $\mathrm{C} 57 / \mathrm{Bl}$ receiving i.p. injections for $8 \mathrm{~d}$ with $0.9 \% \mathrm{w} / \mathrm{v} \mathrm{NaCl}$ (vehicle) or $5 \mu \mathrm{g}$ rhVEGF $_{165} \mathrm{~b}$. ALT = alanine transaminase, $\mathrm{ALP}=$ alkaline phosphatase and GGT $=$ gamma glutamyl transpeptidase ( $n=3$ mice per enzyme test, $p>0.05$ one-way ANOVA). 
(D) Infusion of $5 \mu \mathrm{g}$ rhVEGF 165 b through the external jugular vein led to no change in blood pressure measured through a cannulation of the carotid artery compared with saline injection (vehicle). 